\title{
Correction to: Genotype by environment interactions and agronomic performance of doubled haploids testcross maize (Zea mays L.) hybrids
}

\author{
Julius Pyton Sserumaga - Sylvester O. Oikeh - Stephen Mugo • \\ Godfrey Asea - Michael Otim • Yoseph Beyene - Grace Abalo • \\ Joseph Kikafunda
}

Published online: 22 October 2018

(C) The Author(s) 2018

\section{Correction to: Euphytica (2016) 207:353-365 https://doi.org/10.1007/s10681-015-1549-2}

The original version of this article was revised because it should have been published with open access which it is at present.
Open Access This article is distributed under the terms of the Creative Commons Attribution 4.0 International License (http:// creativecommons.org/licenses/by/4.0/), which permits unrestricted use, distribution, and reproduction in any medium, provided you give appropriate credit to the original author(s) and the source, provide a link to the Creative Commons license, and indicate if changes were made.
The original article can be found online at https:// doi.org/10.1007/s10681-015-1549-2.

J. P. Sserumaga $(\bowtie) \cdot$ G. Asea · M. Otim ·

G. Abalo · J. Kikafunda

Cereals Program, National Crops Resources Research

Institute (NaCRRI), National Agricultural Research

Organization (NARO), Namulonge,

P.O. Box 7084, Kampala, Uganda

e-mail: j.serumaga@gmail.com

S. O. Oikeh

African Agricultural Technology Foundation (AATF),

P.O. Box 30709-00100, Nairobi, Kenya

S. Mugo · Y. Beyene

International Maize and Wheat Improvement Center

(CIMMYT), ICRAF House, UN Avenue, Gigiri, Village

Market, P.O. Box 1041, Nairobi 00621, Kenya 